\title{
Rat Lungworm Infection in Rodents across Post-Katrina New Orleans, Louisiana, USA
}

Rosalyn C. Rael, Anna C. Peterson, Bruno Ghersi-Chavez, Claudia Riegel, Amy E. Lesen, Michael J. Blum

Rat lungworm (Angiostrongylus cantonensis), a parasitic nematode that can cause eosinophilic meningitis in humans, was first detected in New Orleans, Louisiana, USA, in the mid-1980s and now appears to be widespread in the southeastern United States. We assessed the distribution, prevalence, and intensity of $A$. cantonensis infection in New Orleans by examining lung biopsy samples of rodents trapped at 96 sites in 9 areas in Orleans Parish and 1 area in neighboring St. Bernard Parish during May 2015 through February 2017. These areas were selected to capture contrasting levels of income, flooding, and post-disaster landscape management after Hurricane Katrina in 2005. We detected $A$. cantonensis in all areas and in 3 of the 4 rat species trapped. Overall prevalence was $\approx 38 \%$ but varied by area, host species, and host species co-occurrence. Infection intensity also varied by host species. These findings suggest that socioecological analysis of heterogeneity in definitive and intermediate host infection could improve understanding of health risks across the city.

$\mathrm{C}$ oncern is increasing about the spread of rat lungworm (Angiostrongylus cantonensis), especially in the southeastern United States (1-5). A parasitic nematode carried by intermediate mollusk hosts and definitive rat hosts $(6,7)$, rat lungworm can cause eosinophilic meningitis in humans who become infected by ingesting intermediate hosts or paratenic hosts, such as freshwater shrimp and frogs $(6,7)$. A. cantonensis was first reported in North America from Norway rats (Rattus norvegicus) trapped in New Orleans, Louisiana, USA, along the Mississippi River during April 1986 through February 1987 (8). Later surveys suggest the parasite has since become more widespread in Louisiana. Surveys of intermediate apple snail (Pomacea canaliculata) hosts, for example, detected the parasite in suburban areas of

Author affiliations: Tulane University, New Orleans, Louisiana, USA (R.C. Rael, A.C. Peterson, B. Ghersi-Chavez, A.E. Lesen, M.J. Blum); University of Tennessee, Knoxville, Tennessee, USA (A.C. Peterson, B. Ghersi-Chavez, M.J. Blum); The City of New Orleans Mosquito, Termite, and Rodent Control Board, New Orleans (C. Riegel)

DOI: https://doi.org/10.3201/eid2412.180056
New Orleans $(3,9)$. Infections have also since been reported in nonhuman incidental mammal hosts $(9,10)$, and 2 cases of human eosinophilic meningitis from rat lungworm infection were diagnosed in nearby areas of Louisiana $(11,12)$. Rat lungworm also appears to have become widespread across Florida (9) and has been recently detected in Oklahoma (11).

We trapped rodents across New Orleans to characterize the current distribution, prevalence, and intensity of $A$. cantonensis infection and to determine how these aspects vary according to organismal and ecological characteristics of definitive hosts, including species co-occurrence. This study enabled us to identify factors associated with definitive host infection, which might affect transmission risk across the city and offer further insight into the global progression, surveillance, and control of rodent-associated infectious disease.

\section{Methods}

\section{Study Animals}

We collected rats during May 2015 through February 2017 (following Tulane University [New Orleans, LA, USA] Institutional Animal Care and Use Committee [IACUC] protocol \#0451) during a quantitative population survey across 96 city blocks in 8 neighborhoods in New Orleans, a natural area in Orleans Parish, and an area in neighboring St. Bernard Parish. These areas were selected to capture contrasting levels of income, flooding, and postdisaster landscape management after Hurricane Katrina in 2005 (Figure 1; online Technical Appendix Table 1, https://wwwnc.cdc.gov/EID/ article/24/12/18-0056-Techapp1.pdf) (13,14). We selected $8-10$ sites in each study area by random stratification across a $1-\mathrm{km}$ resolution grid spanning the city. Each site was visited 4 times during May 2015 through January 2017: once during summer and once during winter months each year, except for sites in St. Bernard Parish, which were visited only twice (summer 2016 and winter 2016-17). During each trapping period, 30 Tomahawk Live traps (Hazelhurst, WI, USA) were set in locations with potential or evident rodent activity for a minimum of 3 consecutive nights. Trapping efforts continued at each site until no additional rats were 
captured. Sherman traps (H.B. Sherman Traps, Inc., Tallahassee, FL, USA) were also placed at a subset of 48 sites to capture smaller rodents following the same approach (Tulane University IACUC protocol \#0460).

All rodents were necropsied after euthanasia following Tulane University IACUC protocols \#0451 and \#0460. We recorded standard weight and length measurements, as well as species identity; sex; sexual maturity; and, in females, parity. We categorized all Norway rats and roof rats ( $R$. rattus) into 3 age classes (juvenile, subadult, adult) according to body weight $(15,16)$. Urine, lung, liver, spleen, kidney, and tail tissues were sampled and archived in $-80^{\circ} \mathrm{C}$ freezers. We visually screened lung tissues for parasites, which were isolated, counted, and preserved in $95 \%$ ethanol. Representative lung parasites were identified through PCR (17) (online Technical Appendix; online Technical Appendix Table 2).

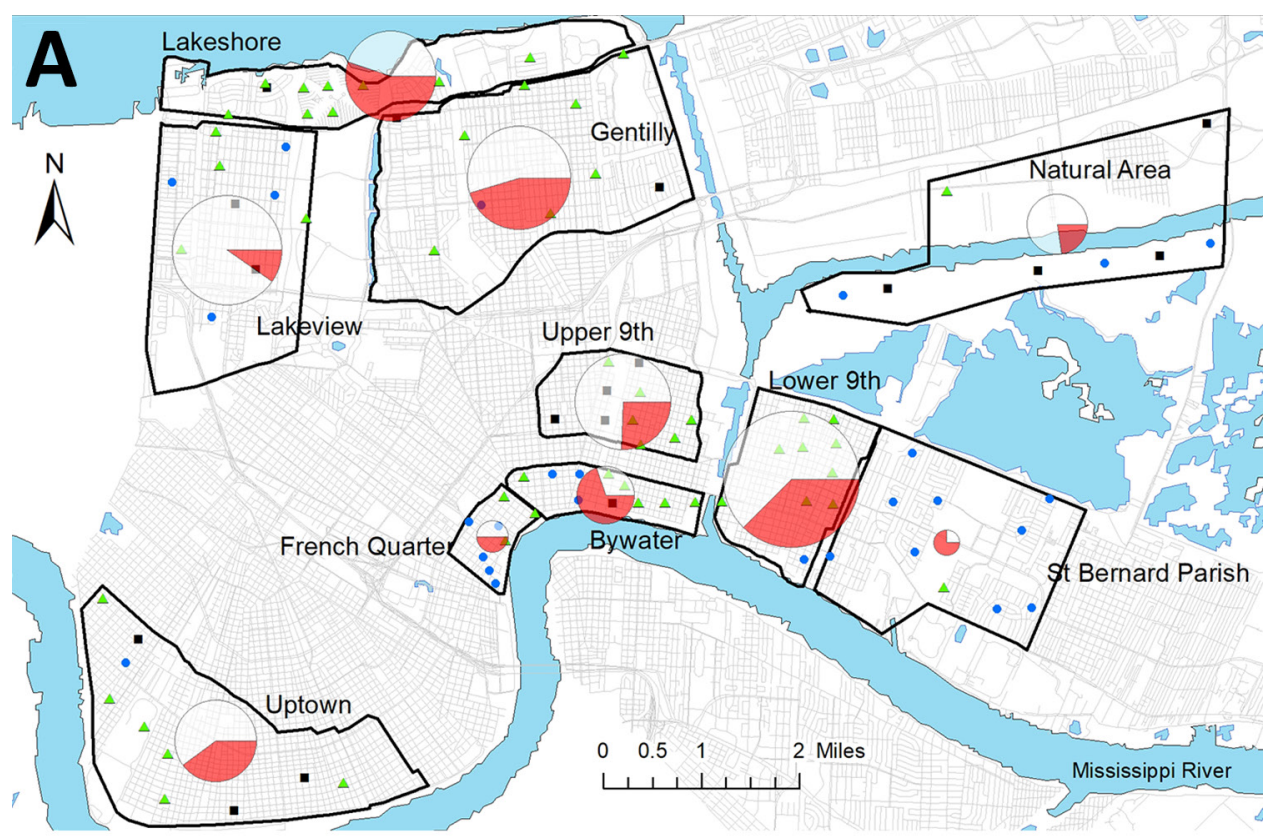

Figure 1. Prevalence of rat lungworm (Angiostrongylus cantonensis) in rodents, New Orleans, Louisiana, USA, May 2015-February 2017. A) Roof rats (Rattus rattus); B) Norway rats (R. norvegicus).

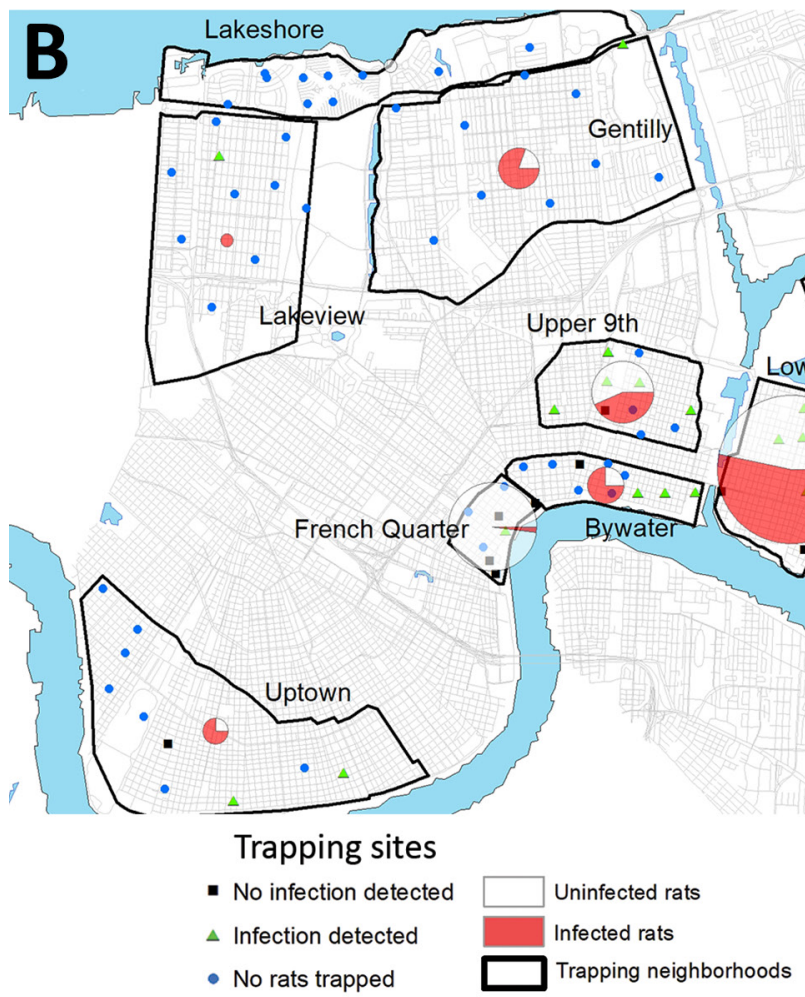




\section{Statistical Analyses}

We report on the distribution and prevalence of $A$. cantonensis according to all species trapped, but additional statistical analyses considered data only from Norway rats and roof rats because of small sample sizes or because the parasite was not detected in other species. Generalized linear models (GLMs) were constructed with a quasibinomial error distribution to determine whether sex or age class was a significant predictor of infection status (i.e., infected, not infected) in Norway rats and roof rats. We ran 3 GLMs: 1 with both Rattus species together and 1 for each species. The same predictors were used in 3 GLMs with a quasi-Poisson distribution to examine relationships with infection intensity (i.e., number of parasites per infected rodent) in Norway rats and roof rats together and separately by species.

We used $\chi^{2}$ tests to determine whether infection prevalence in Norway rats and roof rats differed among study areas, and among sites with 1 versus $>1$ species present. We ran a subset of pairwise tests to compare prevalence among study areas, correcting for multiple comparisons.

We used a Kruskal-Wallis test to compare infection intensity among areas, combining data from Norway rats and roof rats. We used Mann-Whitney U tests to compare infection intensity between Norway rats and roof rats and to compare intensity among sites with 1 or $>1$ species present. We conducted all statistical analyses using $\mathrm{R}$ version 3.4 .2 (https://www.r-project.org/).

\section{Results}

\section{Rodent Trapping and Overall Prevalence of A. cantonensis}

A total of 696 rats were trapped at 78 of the 96 sampling sites. Both Norway rats and roof rats were found in all 10 areas, whereas hispid cotton rats (Sigmodon hispidus) were found in the natural area and the Lower 9th Ward, and rice rats (Oryzomys palustris) were found only in the natural area.

We detected A. cantonensis in all 10 areas (Figure 1) and in 3 of the 4 rat species sampled. Of the 444 roof rats necropsied, $160(36.0 \%)$ were positive for $A$. cantonensis, whereas $101(44.1 \%)$ of 229 Norway rats, 4 (21.1\%) of 19 $S$. hispidus, and 0 of $4 O$. palustris were positive (Table 1). Prevalence differed between Norway rats and roof rats $\left(\chi^{2}=3.810, p=0.051\right)$. Median site-level prevalence estimates for roof rats (33.3\%) and Norway rats (47.2\%) (online Technical Appendix Figure) were similar to those estimated by pooling rats by species and area (Table 1).

A total of 488 house mice (Mus musculus) were collected at 48 locations with Sherman traps. Lungworms were not detected in any house mice, affirming that they do not serve as definitive hosts (18).

\section{Geographic Variation in Prevalence}

Excluding the St. Bernard Parish sites because of small sample sizes $(n=5)$, we found that overall prevalence in both Norway rats and roof rats differed among the sampled areas $\left(\chi^{2}=81.21, \mathrm{p}<0.001\right)$. Rats from the Bywater area exhibited the highest overall prevalence of $A$. cantonensis infection (71\%), whereas rats from the French Quarter exhibited the lowest (8\%) (Table 1; online Technical Appendix; online Technical Appendix Table 3). Most median site-level prevalence values (Figure 2, panel A) were similar to those estimated by pooling rats by species and area (Table 1).

Considering roof rats and Norway rats separately in areas with $\geq 10$ samples, we found that prevalence differed among areas for both species (roof rats, $\chi^{2}=46.755$, $\mathrm{p}<0.0001$; Norway rats, $\left.\chi^{2}=43.62, \mathrm{p}<0.0001\right)$. Prevalence in roof rats was lowest for rats trapped in the Lakeview area $(10 \%)$ and highest for those from the Bywater area (70\%), although pairwise comparisons showed that prevalence differed only among a subset of the study areas (online Technical Appendix; online Technical Appendix Table 4). Prevalence in Norway rats was lowest for rats trapped in the French Quarter (2\%) and highest among those from the Gentilly area (80\%). As with roof rats, prevalence in Norway rats differed only among a subset of the study areas (online Technical Appendix; online Technical Appendix Table 5).

\begin{tabular}{|c|c|c|c|c|c|}
\hline \multirow[b]{2}{*}{ Area } & \multicolumn{5}{|c|}{ No. positive/no. trapped (\%) } \\
\hline & Roof rats & Norway rats & Cotton rats & Rice rats & Total \\
\hline Uptown & $16 / 40(40)$ & $3 / 4(75)$ & - & - & $19 / 44(43)$ \\
\hline Lakeview & $7 / 72(10)$ & $1 / 1(100)$ & - & - & $8 / 73(11)$ \\
\hline Lakeshore & $27 / 49(55)$ & $0 / 1(0)$ & - & - & $27 / 50(54)$ \\
\hline Gentilly & $29 / 64(45)$ & $8 / 10(80)$ & - & - & $37 / 74(50)$ \\
\hline French Quarter & $3 / 6(50)$ & $1 / 47(2)$ & - & - & $4 / 53(8)$ \\
\hline Bywater & $14 / 20(70)$ & $6 / 8(75)$ & - & - & $20 / 28(71)$ \\
\hline Upper 9th & $14 / 55(25)$ & $10 / 23(43)$ & - & - & $24 / 78(31)$ \\
\hline Lower 9th & $42 / 112(38)$ & $71 / 133(53)$ & $0 / 2(0)$ & - & $113 / 247(46)$ \\
\hline Natural area & $5 / 22(23)$ & $0 / 1(0)$ & $4 / 17(24)$ & $0 / 4(0)$ & $9 / 44(20)$ \\
\hline St. Bernard Parish & $3 / 4(75)$ & $1 / 1(1)$ & - & - & $4 / 5(80)$ \\
\hline Total & $160 / 444(36)$ & $101 / 229(44)$ & $4 / 19(21)$ & $0 / 4(0)$ & $265 / 696(38)$ \\
\hline
\end{tabular}




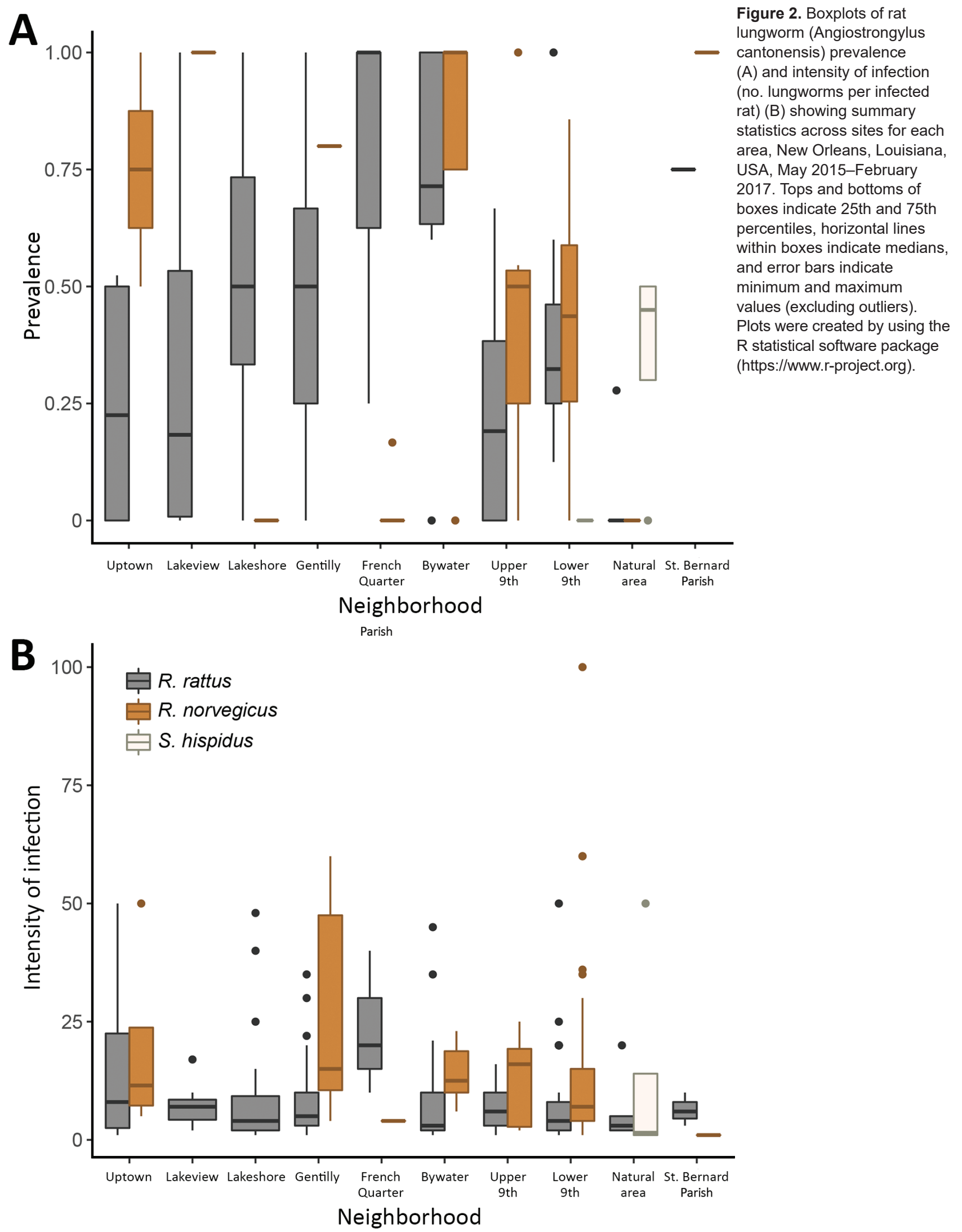


Infection prevalence was significantly lower in sites where only 1 rat species was trapped $(30 \%, \mathrm{n}=267,48$ sites) than in sites that harbored multiple rat species $(44 \%, \mathrm{n}$ $=429,30$ sites $)\left(\chi^{2}=11.654, p<0.001\right)$. However, sites with 1 species had significantly fewer rodents (mean 5.6) than sites with multiple species (mean 14.3) (Mann-Whitney U test, $\mathrm{p}<0.0001$ ).

\section{Likelihood of Infection}

Considering Norway rats and roof rats together, the likelihood of infection did not differ by sex $(\mathrm{df}=656$, coefficient $=0.13133, \mathrm{p}=0.42$ ), but adults were significantly more likely to be infected than juveniles $(\mathrm{df}=656$, coefficient $=$ $-1.26201, \mathrm{p}<0.0001)$ and subadults $(\mathrm{df}=656$, coefficient $=$ -0.42601, $\mathrm{p}<0.05$ ) (online Technical Appendix Table 6).

When we considered species separately, we also detected differences in the likelihood of infection according to age class. The likelihood of infection in Norway rats did not differ by sex $(\mathrm{df}=224$, coefficient $=-0.04621, \mathrm{p}$ $=0.86$ ), but adults were more likely to be infected than either juveniles $(\mathrm{df}=224$, coefficient $=-1.88906, \mathrm{p}=$ $0.003)$ or subadults $(\mathrm{df}=224$, coefficient $=-0.82707, \mathrm{p}$ $=0.007$ ) (online Technical Appendix Table 6). Among roof rats, likelihood of infection did not differ by sex $(\mathrm{df}=$ 427 , coefficient $=0.2305, p=0.26$ ) or between adults and subadults $(\mathrm{df}=427$, coefficient $=-0.1541, \mathrm{p}=0.54)$, but adults were more likely than juveniles to be infected $(\mathrm{df}=$ 427 , coefficient $=-0.9550, \mathrm{p}=0.004)$ (online Technical Appendix Table 6).

\section{Infection Intensity}

Infection intensity (Table 2) significantly differed between roof rats and Norway rats (Mann-Whitney U test, $\mathrm{p}<0.01)$. Considering Norway rats and roof rats together across all areas, infection intensity did not differ by sex $(\mathrm{df}=240$, coefficient $=0.01331, \mathrm{p}=0.972)$. Subadults had lower infection intensity than adults ( $\mathrm{df}=240$, coefficient $=-0.44999, \mathrm{p}=0.0124)$, but juveniles did not $(\mathrm{df}=240$, coefficient $=0.0595, \mathrm{p}=0.82)$ (online Technical Appendix Table 7). Excluding the St. Bernard and French Quarter areas, each of which had only 4 infected rodents, we did not detect significant differences in infection intensity across the sampled areas (Kruskal-Wallis test, $\mathrm{p}=0.484)$. Also, we found no differences in infection intensity between sites with 1 species $(8.75, \mathrm{n}=79)$ versus multiple species present $(11.74, \mathrm{n}=186)$ (MannWhitney $U$ test, $p=0.072)$. Some median site-level intensities within areas (Figure 2, panel B) differed from intensities estimated by pooling all rats of each species within each area (Table 2). When we considered species separately, infection intensity did not differ according to sex or age class for Norway rats (all $p>0.05$ ) or roof rats (all p>0.05) (online Technical Appendix Table 7).

\section{Discussion}

We assessed the current distribution and prevalence of $A$. cantonensis in definitive rat hosts across New Orleans, where the parasite has been present since at least 1986 (8). Our overall estimate of $38 \%$ infection prevalence in New Orleans is comparable to count-based estimates reported for other areas where $A$. cantonensis is considered endemic $(19,20$, but see 21$)$. We also found $A$. cantonensis in rats across New Orleans and in neighboring St. Bernard Parish, which contrasts with the patchy distributions exhibited by other rodent-associated pathogens in cities (22-25). Although rat lungworm is present across New Orleans, infection prevalence varied according to geography and rodent host species, suggesting the risk for transmission to humans might be mediated in part by geographically variable landscape features that affect commensal rats $(13,14)$. It is also likely, however, that the distributions of intermediate hosts and human population densities moderate transmission risk.

The first record of $A$. cantonensis in New Orleans reported lower prevalence in rat hosts than those observed in our study. An overall count-based prevalence of $18 \%$ was

\begin{tabular}{|c|c|c|c|c|c|}
\hline \multirow[b]{2}{*}{ Area } & \multicolumn{5}{|c|}{ Intensity (no. positive) } \\
\hline & Roof rats & Norway rats & Cotton rats & Rice rats & Total \\
\hline Uptown & $13.7(19)$ & $19.5(4)$ & - & - & $14.7(23)$ \\
\hline Lakeview & $8.0(7)$ & - & - & - & $8.0(7)$ \\
\hline Lakeshore & $8.7(23)$ & - & - & - & $8.7(23)$ \\
\hline Gentilly & $8.5(29)$ & $27.9(7)$ & - & - & $12.3(36)$ \\
\hline French Quarter & $23.3(3)$ & 4.0 (1) & - & - & $18.5(4)$ \\
\hline Bywater & $11.1(12)$ & $12.2(5)$ & - & - & 11.4 (17) \\
\hline Upper 9th & 7.1 (15) & $12.3(7)$ & - & - & $8.7(22)$ \\
\hline Lower 9th & $7.7(42)$ & $13.3(65)$ & - & - & $11.1(107)$ \\
\hline Natural area & $6.4(5)$ & - & $13.5(4)$ & - & $9.6(9)$ \\
\hline St. Bernard Parish & $6.3(3)$ & $1(1)$ & - & - & $5.0(4)$ \\
\hline Total & $9.2(158)$ & $14.3(90)$ & $13.5(4)$ & - & $11.1(252)$ \\
\hline
\end{tabular}


found for Norway rats and roof rats trapped in 1986-1987 (8). However, evidence of infection was found only in Norway rats; $A$. cantonensis was detected in $20(21 \%)$ of 94 trapped Norway rats and in 0 of 19 trapped roof rats (8). In comparison, we found overall prevalence $>18 \%$ in 8 of the 10 trapping areas in our study (Table 1), and we detected infected roof rats in all trapping areas. However, it is unclear whether the distribution of rodent host infections has changed, because the 1986-1987 surveys were limited to trapping on wharves along the Mississippi River (8). Thus, although we can affirm that infection prevalence varies by geography and definitive host (8), we cannot conclude that A. cantonensis became more broadly distributed across the city during the past 3 decades.

Evidence of greater prevalence and infection intensity of $A$. cantonensis in adult rats most likely reflects the increasing probability over time that an individual rat will consume an infected intermediate host and that infection becomes more evident in lung tissue. Waugh et al. (19) similarly reported differences in intensity and prevalence in rats from Jamaica according to size but not sex, although an earlier study found that female Norway rats were more likely to be infected (26). Evidence that $A$. cantonensis infection differs by host age contrasts with findings for other urban rodent-associated pathogens, including flea-vectored Bartonella bacteria (25). The finding of distinct Bartonella species in Norway rats and roof rats (25) suggests that co-occurrence does not facilitate pathogen transmission, whereas our results indicate otherwise. Contrasting patterns in the demography of definitive host infection may reflect pathogen-specific differences in transmission pathways. Further study is therefore warranted to determine the roles of definitive host abundance and diversity in pathogen transmission.

It has been more than a decade since the last diagnosed case of rat lungworm infection in the New Orleans area (12), which suggests that factors unrelated to rodent hosts mitigate the risk for transmission to humans. Although the most recent case in Louisiana resulted from consumption of a paratenic host (12), work elsewhere suggests that transmission to humans most likely occurs through accidental consumption of raw or undercooked infected snails on produce (7). Accordingly, the distribution and abundance of infected intermediate hosts are probably key factors affecting transmission risk, especially in cities such as New Orleans, where interest in urban agriculture is on the rise $(27,28)$. It is also possible that risk is influenced by climate-driven spread of invasive mollusks $(29,30)$, such as apple snails, that can serve as reservoirs $(1,3)$. Further study of infection prevalence in intermediate hosts would thus probably improve understanding of transmission risk across New Orleans and other cities that are vulnerable to climate change.
We intentionally diagnosed infection through a visual and count-based survey to draw comparisons to historical records, but implementing complementary approaches could have provided further understanding of $A$. cantonensis infection. As has been noted in prior studies $(19,20)$, count-based approaches probably yield conservative estimates relative to PCR-based approaches of infection. For example, in Hawaii, a count-based approach yielded a prevalence estimate of $54 \%$, whereas PCR yielded an estimate of $100 \%$ (20). More extensive use of PCR-based approaches in our study probably would have afforded additional perspective on parasitism and could also have excluded possible errors due to misidentification (31-33).

Our results indicate that cross-disciplinary analysis of A. cantonensis infection could shed further light on the risk for transmission to humans (34). As has been found with other zoonoses, human risk might correspond to socioecological disparities in habitat and resources favored by infected definitive and intermediate hosts $(22,23,35-38)$. For example, Rael et al. (13) detected a positive correlation between land abandonment and rat abundance in New Orleans across only low-income neighborhoods. The contrasting landscapes (14) and rodent assemblages (Table 1) found in the Lower 9th Ward in New Orleans and in adjacent St. Bernard Parish highlight the possibility that public health risks have been shaped by differences in postdisaster (i.e., Hurricane Katrina) land management policies (29). Although too few rats were trapped in St. Bernard Parish (n $=5$ ) to confidently estimate rat lungworm prevalence (Table 1), the observed differences in rat abundance suggest that transmission risk sharply differs between the Lower 9th Ward and St. Bernard Parish. Thus, further study of associations between definitive and intermediate host infection and socioecological factors probably would better define transmission risk across the city $(14,39)$.

Although rat lungworm is just 1 of many pathogens harbored by urban rats $(40,41)$, citywide estimates of host infection like those presented here can provide an epidemiologic baseline that can improve understanding of infectious disease dynamics in cities. Baselines are particularly informative for cities where zoonotic pathogens are likely to (re) emerge because of shifting climate conditions $(30,40,42)$ or extreme events, such as hurricanes, that can foster disease outbreaks (13). New Orleans unenviably straddles both sets of circumstances (43-45). Accordingly, further study of rat lungworm could help inform public health policies, surveillance programs, and intervention to safeguard the well-being of vulnerable communities in New Orleans and elsewhere.

\section{Acknowledgments}

We thank the investigators of the Coupled Natural and Human Systems-New Orleans project team for collaborations that supported this work. 
The Tulane-Xavier Center for Bioenvironmental Research, the Tulane ByWater Institute, the National Science Foundation (BCS-0948993, BCS-1313703), and the Louisiana Board of Regents provided funding for this work.

\section{About the Author}

Dr. Rael is a mathematical biologist involved in research on coupled human and natural systems at the ByWater Institute of Tulane University. Her research interests include modeling ecological interactions and infectious disease epidemiology.

\section{References}

1. Stockdale Walden HD, Slapcinsky JD, Roff S, Mendieta Calle J, Diaz Goodwin Z, Stern J, et al. Geographic distribution of Angiostrongylus cantonensis in wild rats (Rattus rattus) and terrestrial snails in Florida, USA. PLoS One. 2017;12:e177910. http://dx.doi.org/10.1371/journal.pone.0177910

2. Al Hammoud R, Nayes SL, Murphy JR, Heresi GP, Butler IJ, Pérez N. Angiostrongylus cantonensis meningitis and myelitis, Texas, USA. Emerg Infect Dis. 2017;23:1037-8. http://dx.doi.org/ 10.3201/eid2306.161683

3. Teem JL, Qvarnstrom Y, Bishop HS, da Silva AJ, Carter J, White-McLean J, et al. The occurrence of the rat lungworm, Angiostrongylus cantonensis, in nonindigenous snails in the Gulf of Mexico region of the United States. Hawaii J Med Public Health. 2013;72(Suppl 2):11-4.

4. York EM, Creecy JP, Lord WD, Caire W. Geographic range expansion for rat lungworm in North America. Emerg Infect Dis. 2015;21:1234-6. http://dx.doi.org/10.3201/eid2107.141980

5. Lv S, Zhang Y, Steinmann P, Yang GJ, Yang K, Zhou XN, et al. The emergence of angiostrongyliasis in the People's Republic of China: the interplay between invasive snails, climate change and transmission dynamics. Freshw Biol. 2011;56:717-34. http://dx.doi.org/10.1111/j.1365-2427.2011.02579.x

6. Alicata JE. Biology and distribution of the rat lungworm, Angiostrongylus cantonensis, and its relationship to eosinophilic meningoencephalitis and other neurological disorders of man and animals. Adv Parasitol. 1965;3:223-48. http://dx.doi.org/10.1016/ S0065-308X(08)60366-8

7. Cowie RH. Biology, systematics, life cycle, and distribution of Angiostrongylus cantonensis, the cause of rat lungworm disease. Hawaii J Med Public Health. 2013;72(Suppl 2):6-9.

8. Campbell BG, Little MD. The finding of Angiostrongylus cantonensis in rats in New Orleans. Am J Trop Med Hyg. 1988;38:568-73. http://dx.doi.org/10.4269/ajtmh.1988.38.568

9. Kim DY, Stewart TB, Bauer RW, Mitchell M. Parastrongylus (=Angiostrongylus) cantonensis now endemic in Louisiana wildlife. J Parasitol. 2002;88:1024-6. http://dx.doi.org/10.1645/ 0022-3395(2002)088[1024:PACNEI]2.0.CO;2

10. Gardiner CH, Wells S, Gutter AE, Fitzgerald L, Anderson DC, Harris RK, et al. Eosinophilic meningoencephalitis due to Angiostrongylus cantonensis as the cause of death in captive nonhuman primates. Am J Trop Med Hyg. 1990;42:70-4. http://dx.doi.org/10.4269/ajtmh.1990.42.70

11. New D, Little MD, Cross J. Angiostrongylus cantonensis infection from eating raw snails. N Engl J Med. 1995;332:1105-6. http://dx.doi.org/10.1056/NEJM199504203321619

12. Louisiana Office of Public Health. Angiostrongylus cantonensis annual report 2016 [cited 2017 Nov 30]. http://new.dhh.louisiana. gov/assets/oph/Center-PHCH/Center-CH/infectious-epi/ Annuals/Acantonensis LaIDAnnual.pdf

13. Rael RC, Peterson AC, Ghersi BM, Childs J, Blum MJ. Disturbance, reassembly, and disease risk in socioecological systems.
EcoHealth. 2016;13:450-5. http://dx.doi.org/10.1007/ s10393-016-1157-1

14. Lewis JA, Zipperer WC, Ernstson H, Bernik B, Hazen R, Elmqvist T, et al. Socioecological disparities in New Orleans following Hurricane Katrina. Ecosphere. 2017;8:e01922. http://dx.doi.org/10.1002/ecs2.1922

15. McGuire B, Pizzuto T, Bemis WE, Getz LL. General ecology of a rural population of Norway rats (Rattus norvegicus) based on intensive live trapping. Am Midl Nat. 2006;155:221-36. http://dx.doi. org/ 10.1674/0003-0031(2006)155[0221:GEOARP]2.0.CO;2

16. King CM, Innes JG, Gleeson D, Fitzgerald N, Winstanley T, O'Brien B, et al. Reinvasion by ship rats (Rattus rattus) of forest fragments after eradication. Biol Invasions. 2011;13:2391-408. http://dx.doi.org/10.1007/s10530-011-0051-6

17. Eamsobhana P, Lim PE, Solano G, Zhang H, Gan X, Yong HS. Molecular differentiation of Angiostrongylus taxa (Nematoda: Angiostrongylidae) by cytochrome c oxidase subunit I (COI) gene sequences. Acta Trop. 2010;116:152-6. http://dx.doi.org/10.1016/ j.actatropica.2010.07.005

18. Yamashita T, Sato Y, Shiraki T, Otsuru M, Suzuki T. Development of Angiostrongylus cantonensis in rats, mice and guinea-pigs. Japanese J Parasitol. 1975;24:114-21.

19. Waugh CA, Lindo JF, Lorenzo-Morales J, Robinson RD. An epidemiological study of $A$. cantonensis in Jamaica subsequent to an outbreak of human cases of eosinophilic meningitis in 2000. Parasitology. 2016;143:1211-7. http://dx.doi.org/10.1017/ S0031182016000640

20. Qvarnstrom Y, Bishop HS, da Silva AJ. Detection of rat lungworm in intermediate, definitive, and paratenic hosts obtained from environmental sources. Hawaii J Med Public Health. 2013; 72(Suppl 2):63-9.

21. Zhang RL, Chen MX, Gao ST, Geng YJ, Huang DN, Liu JP, et al. Enzootic angiostrongyliasis in Shenzhen, China. Emerg Infect Dis. 2008;14:1955-6. http://dx.doi.org/10.3201/eid1412.080695

22. Costa F, Ribeiro GS, Felzemburgh RDM, Santos N, Reis RB, Santos AC, et al. Influence of household rat infestation on Leptospira transmission in the urban slum environment. PLoS Negl Trop Dis. 2014;8:e3338. http://dx.doi.org/10.1371/journal.pntd.0003338

23. Ko AI, Galvão Reis M, Ribeiro Dourado CM, Johnson WD Jr, Riley LW; Salvador Leptospirosis Study Group. Urban epidemic of severe leptospirosis in Brazil. Lancet. 1999;354:820-5. http://dx.doi.org/10.1016/S0140-6736(99)80012-9

24. Himsworth CG, Bai Y, Kosoy MY, Wood H, DiBernardo A, Lindsay R, et al. An investigation of Bartonella spp., Rickettsia typhi, and Seoul hantavirus in rats (Rattus spp.) from an inner-city neighborhood of Vancouver, Canada: is pathogen presence a reflection of global and local rat population structure? Vector Borne Zoonotic Dis. 2015;15:21-6. http://dx.doi.org/10.1089/ vbz.2014.1657

25. Peterson AC, Ghersi BM, Alda F, Firth C, Frye MJ, Bai Y, et al. Rodent-borne Bartonella infection varies according to host species within and among cities. EcoHealth. 2017;14:771-82. http://dx.doi.org/10.1007/s10393-017-1291-4

26. Waugh CA, Lindo JF, Foronda P, Ángeles-Santana M, Lorenzo-Morales J, Robinson RD. Population distribution and zoonotic potential of gastrointestinal helminths of wild rats Rattus rattus and $R$. norvegicus from Jamaica. J Parasitol. 2006;92:10148. http://dx.doi.org/10.1645/GE-795R1.1

27. McMillan T. 5 Urban farms reshaping the food world in New Orleans. The Atlantic. 2010 Nov 12 [cited 2018 Jan 1] https://www.theatlantic.com/health/archive/2010/11/5-urbanfarms-reshaping-the-food-world-in-new-orleans/66473/

28. Langenhennig S. Seeds and the city: urban lots are sprouting farms across New Orleans. NOLA.com. 2015 Jun 17 [cited 2018 Jan 01]. http://www.nola.com/homegarden/index.ssf/2015/06/seeds_and_ the_city_a_network_o.html 
29. Morand S, Bordes F, Chen HW, Claude J, Cosson JF, Galan M, et al. Global parasite and Rattus rodent invasions: The consequences for rodent-borne diseases. Integr Zool. 2015;10:409-23. http://dx.doi.org/10.1111/1749-4877.12143

30. Mazza G, Tricarico E, Genovesi P, Gherardi F. Biological invaders are threats to human health: An overview. Ethol Ecol Evol. 2014;26:112-29. http://dx.doi.org/10.1080/03949370.2013.863225

31. Kinsella JM. Studies on the life cycle and host specificity of Parastrongylus schmidti (Nematoda: Angiostrongylidae). Proc Helminthol Soc Wash. 1987;54:245-8.

32. Spratt DM. Species of Angiostrongylus (Nematoda: Metastrongyloidea) in wildlife: A review. Int J Parasitol Parasites Wildl. 2015;4:178-89. http://dx.doi.org/10.1016/j.ijppaw.2015.02.006

33. Miller CL, Kinsella JM, Garner MM, Evans S, Gullett PA, Schmidt RE. Endemic infections of Parastrongylus (=Angiostrongylus) costaricensis in two species of nonhuman primates, raccoons, and an opossum from Miami, Florida. J Parasitol. 2006;92:406-8. http://dx.doi.org/10.1645/GE-653R.1

34. Grisotti M, Avila-Pires FD. Worms, slugs and humans: the medical and popular construction of an emerging infectious disease. Hist Cienc Saude Manguinhos. 2011;18:877-91. http://dx.doi.org/10.1590/S0104-59702011000300016

35. Mills JN, Childs JE. Ecologic studies of rodent reservoirs: their relevance for human health. Emerg Infect Dis. 1998;4:529-37. http://dx.doi.org/10.3201/eid0404.980403

36. Macpherson CNL. Human behaviour and the epidemiology of parasitic zoonoses. Int J Parasitol. 2005;35:1319-31. http://dx.doi.org/10.1016/j.ijpara.2005.06.004

37. Neiderud C-J. How urbanization affects the epidemiology of emerging infectious diseases. Infect Ecol Epidemiol. 2015;5:27060. http://dx.doi.org/10.3402/iee.v5.27060

38. Bradley CA, Altizer S. Urbanization and the ecology of wildlife diseases. Trends Ecol Evol. 2007;22:95-102. http://dx.doi.org/ 10.1016/j.tree.2006.11.001

39. Gulachenski A, Ghersi BM, Lesen AE, Blum MJ. Abandonment, ecological assembly and public health risks in counter-urbanizing cities. Sustainability. 2016;8:491. http://dx.doi.org/10.3390/ su8050491

40. Jones KE, Patel NG, Levy MA, Storeygard A, Balk D, Gittleman JL, et al. Global trends in emerging infectious diseases. Nature. 2008;451:990-3. http://dx.doi.org/10.1038/nature06536

41. Lloyd-Smith JO, George D, Pepin KM, Pitzer VE, Pulliam JRC, Dobson AP, et al. Epidemic dynamics at the human-animal interface. Science. 2009;326:1362-7. http://dx.doi.org/10.1126/ science. 1177345

42. Gubler DJ, Reiter P, Ebi KL, Yap W, Nasci R, Patz JA. Climate variability and change in the United States: potential impacts on vector- and rodent-borne diseases. Environ Health Perspect. 2001;109(Suppl 2):223-33. http://dx.doi.org/10.2307/3435012

43. Dorn PL, Perniciaro L, Yabsley MJ, Roellig DM, Balsamo G, Diaz J, et al. Autochthonous transmission of Trypanosoma cruzi, Louisiana. Emerg Infect Dis. 2007;13:605-7. http://dx.doi.org/ 10.3201/eid1304.061002

44. Allen T, Murray KA, Zambrana-Torrelio C, Morse SS, Rondinini C, Di Marco M, et al. Global hotspots and correlates of emerging zoonotic diseases. Nat Commun. 2017;8:1124. http://dx.doi.org/10.1038/s41467-017-00923-8

45. Hotez PJ, Jackson Lee S. US Gulf Coast states: The rise of neglected tropical diseases in "flyover nation". PLoS Neg1 Trop Dis. 2017;11:e0005744. http://dx.doi.org/10.1371/ journal.pntd.0005744

Address for correspondence: Rosalyn C. Rael, The ByWater Institute, 627 Lindy Boggs Center, 6823 St. Charles Ave, Tulane University, New Orleans, LA 70118, USA; email: rosalyn.rael@gmail.com

\section{EID Podcast Rat Lungworm Expands into North America}

\section{The rat lungworm, Angostronghlus (Paratrongliles) contonenis causes} eosinophilic meningitis in humans and various disease symptoms in atypical host species, including wildlife and captive animals.

\section{Emily York, integrated pest} management specialist at the Sam Noble Museum of Natural History, discusses the rat lungworm expansion in North America.

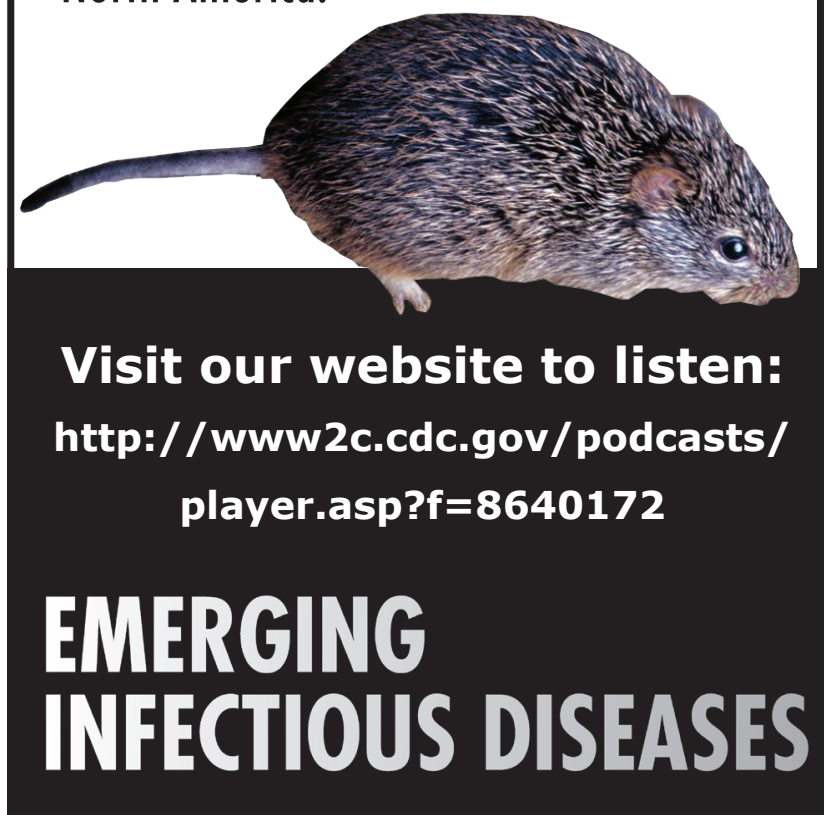

